\title{
Reframing The Curriculum: Making Education for Sustainable Development (ESD) in Action
}

\author{
Eny S. Rosyidatun \\ Syarif Hidayatullah State Islamic University Jakarta, Jl. Ir. H. Djuanda 95, Ciputat, Indonesia \\ Corresponding e-mail: munasprianto ramli@uinjkt.ac.id
}

\begin{abstract}
Many people in the world have been paying more attention and concern on issues in environmental field since a significant climate and environmental changes happens. The global warming phenomenon which is relevant to greenhouse effect, ozone layers destruction, coral reef bleaching, and floods, became alarm clock which awaking global world citizens to think and take actions to prevent human beings from worse situation. As human beings, we have to consider that our earth is not only for our generation, but also for our next generations. It is important to shift the common perception that this earth is treasure from our ancients to the perception that this earth is like a "loan" from our children and grandchildren. So that, it is very important to maintain the balance of using the natural resources on the one hand, and keeping ecosystem good for all creatures on the other hand. Responding this condition, UNESCO has been initiating a program entitled Education for Sustainable Development (ESD) since 1990s. Indonesia as a part of global world citizen has been supporting this program through the government policies. "New curriculum" of 2013 has been established in schools in Indonesia. Despite the controversy of new curriculum policies and problems, the character of 2013 Curriculum could be very potential to drive ESD in action. This curriculum put more attention to affective and psychomotor aspects compare to the formers. It is hoped that integrating ESD into 2013 curriculum would prepare students not only the knowledge of environment responsibility, but also participating in that responsibility. However, the implementation of the curriculum is "trapped" in cognitive area, while the environment is urgently in need of real actions. This paper presents a preliminary stage of a three-year project on environmental education in South Tangerang, Indonesia. It discusses an alternative curriculum of environment education in junior high schools. The curriculum includes the scopes of themes and outcome competencies that showing students' participation. This curriculum has national curriculum and Tbilisi Declaration (1977) as main references.
\end{abstract}

Keywords: curriculum, ESD, action, environmental

\section{INTRODUCTION}

Human beings are facing problems caused by industrial and development boost. Climate and environmental changes have been provoking many people in the world to pay more concern on issues in environmental field. The greenhouse effect, ozone layers destruction, coral reef bleaching, floods, and global warming phenomena became an alarm clock which awaking global world citizens to think and take actions to prevent human beings from worse situation. We, as human beings, have to consider that our earth is not only for our generation, but also for our next generations. It is important to shift the common perception that this earth is a treasure from our ancients to the perception that this earth is like a "loan" from our children and grandchildren, which we have to pay back. So that, it is very important to maintain the balance of using the natural resources on the one hand, and keeping ecosystem good for all creatures on the other hand.

Sustainable development has been socialized in our global community to maintain both of the growth of economic and industrial fields and the balance of 
ecosystem in harmony. Sustainable development is one of the results of universal agreement at Rio de Jenairo, Brazil in June 1992. As a response to the decreasing quality of environment and sustainable development concept, UNESCO has been initiating a specific program. This program entitled Education for Sustainable Development (ESD). Indonesia as a part of global world citizen has been supporting this program through the government policies. In education policies, which issued by the Ministry of Education and Culture (MoEC) of Indonesia, Education for Sustainable Development values has been addressed in the curriculum especially in elementary, senior high, and high school curriculum (MoEC, 2010; Rosyidatun, 2014). However, the implementation of ESD in schools learning activities is not yet fulfilled. Only several institutions of school or subjects that inserted ESD in the learning process (Listiawati, 2013; Rohmah, 2014).

School curriculum in Indonesia is called by its year of establishment. "New curriculum" has been established in schools in Indonesia since 2013. Despite the controversy of new curriculum policies and problems, the character of 2013 Curriculum could be very potential to drive ESD in action. This curriculum put more attention to affective and psychomotor aspect compare to the formers (Table 1). It is hoped that integrating ESD into 2013 curriculum would give more in preparing students not only the knowledge of environment responsibility, but also participating in that responsibility.

Table 1. Comparison of Characteristics of Curriculums Established in Indonesia

\begin{tabular}{|c|c|c|}
\hline$<1994$ & $2004 / 2006$ & Curr. 2013 \\
\hline Content-based & Product-based & Practice-based \\
\hline $\begin{array}{l}\text { Focus on } \\
\text { cognitive } \\
\text { domain }\end{array}$ & $\begin{array}{l}\text { Subjects } \\
\text { contribute to } \\
\text { certain } \\
\text { competencies }\end{array}$ & $\begin{array}{l}\text { Subjects } \\
\text { contribute to ALL } \\
\text { competencies }\end{array}$ \\
\hline $\begin{array}{l}\text { Stressing on } \\
\text { Plan }\end{array}$ & $\begin{array}{l}\text { Stressing on } \\
\text { Product }\end{array}$ & $\begin{array}{l}\text { Stressing on the } \\
\text { harmony of Plan, } \\
\text { Process, and } \\
\text { Product }\end{array}$ \\
\hline $\begin{array}{l}\text { Monitoring on } \\
\text { implementatio } \\
n \quad \text { of } \\
\text { standardized } \\
\text { lesson Plan }\end{array}$ & $\begin{array}{l}\text { Tight evaluation } \\
\text { e.g. National Test }\end{array}$ & $\begin{array}{l}\text { Assessment of } \\
\text { process and } \\
\text { product as a } \\
\text { whole }\end{array}$ \\
\hline $\begin{array}{l}\text { Content as } \\
\text { Context }\end{array}$ & $\begin{array}{l}\text { Content } \\
\text { Context }\end{array}$ & $\begin{array}{l}\text { Popular theme as } \\
\text { Context }\end{array}$ \\
\hline
\end{tabular}

One definition of sustainable development is development of industrial and natural resources that meets the energy needs of present without compromising the ability of future generations to meet their needs in similar manner. Some experts acknowledge the concept of triple P: Planet, People, and Profit (Susilo, 2008). It is about how to keep all the "P"s growing in harmony. ESD started from the awareness of the importance of the earth's sustainability. To guarantee the sustainability of the earth, it is a must to conduct the awareness early. Only through education a movement would impact significantly. Based on that premises, UNESCO, as a UN body that focuses on education and culture, campaigned ESD program.

UNESCO projected to achieve all ESD targets in ten years period which known as DESD (Decade of ESD). As stated in the UN's $57^{\text {th }}$ general assembly, DESD goes through the year of 2005 to the year of 2014. Indonesia, as a nation in the world supports this program. The 2010 Indonesian Ministry of National Education's strategic plans (Renstra) stated that education has to plant understanding of the sustainability and the balance of ecosystem (MoEC, 2010). At least, there are values to be developed as commitment to ESD program. Firstly, the value of appreciating all rights of human beings on the earth and commitment to social justice and economic for all. Secondly, appreciating future human rights and commitment to intergenerational responsibility. Thirdly, appreciating and caring to the life of a community with its diversity which includes preservation and rehabilitation of the earth's ecosystems. Fourthly, appreciating cultural diversity and commitment to build local and global culture of tolerances, peaceful, and non-violence.

ESD could be viewed as a future-oriented social engineering. It is binding all nations in the world that signed the agreement. It is different from other local and individual ethics such as biocentrism, ecocentrism, and ecofeminism. Human beings are at the centre of concern for sustainable development. They are entitled to a healthy and productive life in harmony with the nature. There are at least five principles to be underlined: 1) intergenerational equity: the right to development must be fulfilled so as to equitably meet development and environmental needs of present and future generations. 2) Equality in one generation: to reduce the gap between social class 3 ) early protection of environment from damage 4) preservation of biodiversity: indigenous people and their communities and other local communities have a vital role in environmental management and development because of their knowledge and 
traditional practices. State should recognize and duly support their indignity, culture, and interests and enable their effective participation in the achievement of sustainable development. 5) Internalization of environment fee in decision making and incentives to support behavioural changes (Susilo, 2008).

In international context, many countries already put ESD as values that should be embedded in courses curriculum in various fields and levels of education (Pavlova, 2010; Sleurs, 2008; Mochizuki \& Fadeeva, 2010; UNESCO, 2014). Moreover, curriculums of teacher training are also concerning ESD. So that, pre-service teachers are provided with ESD values to be applied in their schools later on.

In nature and generally, ESD is very close to science courses (Supriyadi, 2008). However, Pavlova (2010) reported that more and more academics are involved in ESD research and more emphasis is placed on the social aspects of ESD. In Indonesian context, the government already put emphasis on the implementation of ESD in classrooms (MoEc, 2010). Moreover, several institutions get cooperation with schools to implement ESD (Listiawati, 2013). However, as what happened globally, the effort is still fragmented and the breadth of issues addressed is also limited (Pavlova, 2010).

The awareness of the importance of ESD is significantly raised. In terms of embedding ESD in curriculum, Hopkinson and James (2010) argued that reformist approaches to curriculum re-orientation are more likely to be successful than calls for radical, transformational models. Since there is local/district curriculum to go along with national curriculum, such a "new form" of curriculum could be developed to accommodate ESD.
South Tangerang is one of districts of Banten Province in Indonesia. This district is building the character of smart city which one of the missions is becoming an environment-friendly city. Thus, there is subject of environmental education established as local curriculum. Since citizens' behavioural changes are needed to improve environment quality, the curriculum needs to be developed in more 'action' shape. This leads to the scheme of a curriculum reframing, specifically for environmental education curriculum.

\section{METHODS}

In the study, used the following methods: descriptive, the classification method, the method of analysis and synthesis, the methods of generalization and specification.

\section{RESULTS AND DISCUSSION}

This project involves several institutions in order to gain comprehensive point of views. Besides MoEC, academics from several universities and NGO are in the project team. The project will be carried out in three year. The first year is for preparation, the second year is for implementation, and the third year is for evaluation.

Environmental education curriculum draft is one output of the first year works. This draft was developed with several references. The main references were national curriculum (2016) and Tbilisi Declaration documents. 
Table 2. Example of learning outcome of environmental education based on the scope of themes

$\begin{array}{llll}\text { Category } & \text { Our Surrounding } & \text { Our Environment } & \text { Environmental Issues } \\ \text { Conservation }\end{array}$

Feel excited about the local, regional, and national program of Reduce,

Reuse, Recycle, and Refuse plastic bag (4R)

Feel sad with various disasters happened and the number of victim in every disaster occured both regionally and nationally

Demonstrate an attitude to help in avoiding and decreasing the disaster impact
Feel excited with the implementation of green technology in local, regional and national scope; and demonstrate willingness to implement green technology locally
Feel sad with the loss of biodiversity that occuring locally, regionally and nationally
Agree on the implementation of simple green technologyin surrounding environment
Demonstrate deep concern in biodiversity as well as its problems
Design an implementation of 4R program in daily activities as a student either at home, school, or community
Identify types dan factors of disaster that probably occurs locally and nationally through literature review and interview with experts
Identify the green technology locally, regionally and nationally; and design simple green technology works
Describe the functions, roles, and benefits of biodiversity in biosphere as well as its problems in

local, regional and national environmental contexts
Present the 4R design as an attempt in environmental conservation
Draw the disaster area maps locally and establish disaster mitigation efforts
Present the implementation works of green technology for surrounding environment
Present the functions and roles of biodiversity in biosphere as well as its

problems in local,

regional and national environmental contexts
Collaboratively practice the $4 \mathrm{R}$

5 program in daily lives either at home, school, or community
Disseminate posters to local community against disaster and the mitigation efforts
Create a simple green teachnology works in mutual cooperation
Carry out a loca

campaign for

biodiversity conservation

Notes: 1: Awareness, 2: Attitude, 3: Knowledge 4: Skill 5: Participation 


\subsection{References of Curriculum Development}

Environmental education curriculum for junior high school in South Tangerang is designed with reference to national curriculum policy (MoEC, 2016) and Tbilisi Declaration (1977). National curriculum of Indonesia suggested that for junior high school level, learning process should cover local, national, and regional context. It means that various environmental issues from time to time have to be incorporated in the lessons.

Tbilisi Declaration (1977) was adopted by acclamation in the first intergovernmental conference on environmental education. It was organized by the UNESCO and UNEP. There were 68 states participated in the event that convened in Tbilisi, Georgia. Tbilisi Declaration recommended five categories of environmental education objectives. They are awareness, knowledge, attitudes, skills, and participation. Awareness is to help social groups and individuals acquire an awareness and sensitivity to the total environment and its allied problems. Knowledge is to help social groups and individuals gain a variety of experience in, and acquire a basic understanding of the environment and its associated problems. Attitudes is to help social groups and individuals acquire a set of values and feelings of concerns for the environment and motivation for actively participating in environmental improvement and protection. Skill is to help social groups and individuals acquire the skills for identifying and solving environmental problems. Participation is to provide social groups and individuals with an opportunity to be actively involved at all levels in working toward resolution of environmental problems.

It is argued that adopting Tbilisi Declaration's categories of environmental education objective would put learning process in more active ways. Students would be provided chances to practice in the real life.

\subsection{Scope of Themes}

There are four scopes of themes to deliver ESD in this curriculum. The first is "our surrounding" that describes wastes, 4R, and life as consumer. The second is "our environment" that describes ecosystem, water pollution, solid pollution, air pollution, health, and disaster mitigation. The third is "environmental issues" that describes energy, global warming, and green technology. The fourth is "conservation of environment" that describes biodiversity and how to appreciate the nature. These scopes of themes are generated from current national curriculum policies.
Table 2 describes examples of learning outcome of environmental education curriculum. The learning outcome is stated as competencies in each aspect of awareness, attitude, knowledge, skill, and participation. Teachers would refer to these competencies in designing environmental education lesson plans.

It is hoped that once this curriculum implemented, teachers and students will be involved in the community to build better environment. It will be a starting point to make South Tangerang as a green city comes true. Thus, this curriculum would be a model for other subjects' curriculum which need to integrate ESD values in to the curriculums.

\section{CONCLUSIONS}

The environmental education curriculum as local curriculum in South Tangerang district is designed with referring to Tbilisi declaration (1977). With the five categories of environmental education objectives, namely awareness, knowledge, attitudes, skills, and participation, the lesson would not only deal with cognitive aspect of thinking, but also about action. The coverage context recommended by national curriculum which includes local, national, and regional context would drive the lesson in to a broader point of views.

\section{ACKNOWLEDGEMENTS}

This paper is a part of preliminary project between Tangerang Selatan District office of MOEC, JICA, and IEPF. Special thanks to Dr. Yanti Herlanti who has been encouraging in developing this project as well as involving various academic colleagues.

\section{REFERENCES}

Hopkinson, P., James, P. (2010). Practical pedagogy for embedding ESD in science, technology, engineering and mathematics curricula. International Journal of Sustainability in Higher Education, 11(4), 365-379,

Mochizuki, Y., Fadeeva, Z. (2010). Competences for sustainable development and sustainability: Significance and challenges for ESD. International Journal of Sustainability in Higher Education, 11(4), 391-403.

MoEC. (2010). Executive summary of ESD: Principle contents, guideline and model of implementation. ISBN 978-602-8613-13-2 
MoEC. (2016). Curriculum Updates. Available at http://www.kemdikbud.go.id/

Listiawati, N. (2013). The Implementation of ESD in Several Institutions. Jurnal Pendidikan dan Kebudayaan, 19(3).

Pavlova, M. (2013). Teaching and Learning for Sustainable Development: ESD Research in Technology Education. Int J Technol Des Educ, 23, 733.

Rohmah, L. (2014). Implementation of ESD-based Curriculum at International Luqman Hakim Islamic Elementary School, Yogyakarta. AlBidayah, 6(2).

Rosyidatun, E. S. (2014). How Well Does the 2013 Curriculum of Indonesia Role in Preparing Students as Education for Sustainable Development (ESD)? Proceeding of Sriwijaya University Learning and Education International Conference.

Sleurs, W. (ed). (2008). Competencies for ESD teachers: a framework to integrate ESD in the curriculum of teacher training institute. Available at http://www.csct-project.org

Supriyadi, T. (2008). Implementation of ESD Values in Science Education. Edusains, 1(2).

Susilo, R. K. D. (2008). Environmental Sociology. Jakarta: RajaGrafindo Persada.

UNESCO \& UNEP. (1977). Tbilisi Declaration. Citing Internet sources at https://www.gdrc.org/uem /ee/tbilisi.html

UNESCO. (2014). Education for Sustainable Development. Citing Internet sources. http://www.unesco.org/ 